\title{
On the first tachinid fly (Diptera, Tachinidae) carrying Asclepiadoideae pollinaria in the Neotropical Region
}

\author{
Silvio Shigueo Nihei ${ }^{1} \&$ Elizabeth de Araujo Schwarz ${ }^{2}$
}

${ }^{1}$ Departamento de Zoologia, Instituto de Biociências, Universidade de São Paulo, Rua do Matão, Travessa 14, n. 101, Cidade Universitária, $05508-900$
São Paulo-SP, Brazil. silvionihei@gmail.com. Fellowship CNPq
${ }^{2}$ Departamento de Botânica, Universidade Federal do Paraná, 81531-980 Curitiba-PR, Brazil. schwbet@ufpr.br

\begin{abstract}
On the first tachinid fly (Diptera, Tachinidae) carrying Asclepiadoideae pollinaria in the Neotropical Region. This paper reports the first Neotropical Tachinidae species possibly associated to pollination of Asclepiadoideae: a female of Euacaulona sumichrasti Townsend, 1908 (Diptera, Tachinidae, Phasiinae, Trichopodini) carrying pollinaria of Gonolobus parviflorus Decne., 1844 (Apocynaceae, Asclepiadoideae, Asclepiadeae: Gonolobinae) attached to its proboscis. The fly specimen was collected in Paraguay, Departamento Canindeyú. The pollinarium is illustrated and described herein. This represents the first anthophilous record to G. parviflorus and to the genus.
\end{abstract}

KEYWORDS. Anthophily; Apocynaceae-Asclepiadoideae; Euacaulona; Gonolobus; pollination; Trichopodini.

RESUMO. Sobre o primeiro taquinídeo (Diptera, Tachinidae) carregando polinários de Asclepiadoideae na Região Neotropical. Esta contribuição relata a primeira espécie neotropical de Tachinidae possivelmente associada à polinização de Asclepiadoideae: uma fêmea de Euacaulona sumichrasti Townsend, 1908 (Diptera, Tachinidae, Phasiinae, Trichopodini) transportando dois polinários de Gonolobus parviflorus Decne., 1844 (Apocynaceae, Asclepiadoideae, Asclepiadeae: Gonolobinae) presos à sua probóscide. O espécime foi coletado no Paraguai, Departamento Canindeyú. O polinário é ilustrado e caracterizado. Este é o primeiro registro de antofilia para G. parviflorus e para o gênero.

PALAVRAS-CHAVE. Antofilia; Apocynaceae-Asclepiadoideae; Euacaulona; Gonolobus; polinização; Trichopodini.

Pollination of Asclepiadoideae (Apocynaceae) flowers occurs with the removal of pollinaria (each pollinarium consisting of a translator apparatus bearing two pollinia on each side) and then the pollinia insertion into the stigmatic chambers, with the removal and transport being performed by insects (Vieira \& Sheperd 1999). Nevertheless, only flower visitation and the ability to carry pollen do not qualify an anthophilous insect as a pollinator (Kevan \& Baker 1983). To be an effective pollinator, it must visit the flowers in such a way as to transfer pollen regularly from anthers to stigmata, either between plants, between flowers on the same plant, or within the same flower (Larson et al. 2001).

Pollination and reproduction of plants have been studied since the eighteen century (Perry 1938). With regard to Asclepiadoideae, Knuth (1909) described in details the pollination in several milkweeds species, providing a list of insects discriminated whether visitors, nectar thieves or pollinators according to the position of the translators found attached to the insect body. Schill \& Jäkel (1978) studied the pollinaria of 408 asclepiad species (including G. parviflorus) under optic, scanning and transmission microscopy techniques. Several collectors have observed (according to the collecting labels) a repulsive scent emitted by the flowers of G. parviflorus. Addi- tionally, Asclepiadoideae is placed first in a list of plant families (Faegri \& van der Pijl 1980) which adopt myiophily, by producing substances which stimulate feeding or ovipositing by flies or by having trapping-flowers.

Diptera appears as the third most recorded insect order pollinating the Asclepiadoideae, after Hymenoptera but close to Lepidoptera. On the other hand, for some groups (Marsdeniae, Ceropegieae and Asclepiadeae-Gonolobinae) the dipteran species play a major role in their pollination system (Ollerton \& Liede 1997). Within the dipterans, the Tachinidae are considered the main pollinators of the Asclepiadeae, while with lower importance (frequency below 20\%) to pollination of remaining species of Asclepiadoideae belonging to Ceropegieae (as 'Stapeliae'), Marsdeniae and AsclepiadeaeGonolobinae (Ollerton \& Liede 1997).

This paper reports the first Neotropical Tachinidae species possibly associated to pollination of Asclepiadoideae. The fly specimen was collected from Paraguay, Departamento Canindeyú. This is also the first anthophilous record to the genus Gonolobus.

Report of the anthophily. We found one female of Euacaulona sumichrasti Townsend, 1908 (Tachinidae, Phasiinae, Trichopodini) carrying pollinaria of Gonolobus 
parviflorus Decne., 1844 (Apocynaceae, Asclepiadoideae, Asclepiadeae, Gonolobinae) attached to its proboscis (Figs. $1,2)$. The tachinid fly specimen was collected from Paraguay, Departamento Canindeyú, Estancia Rio Corrientes $\left(24^{\circ} 05^{\prime} \mathrm{S}, 54^{\circ} 35^{\prime} \mathrm{W}\right)$ on $26-30$ January 1984 by T. Bonace, and is deposited at the Department of Zoology, Universidade Federal do Paraná, Curitiba, Brazil (DZUP).

This tachinid is the single species belonging to genus Euacaulona Townsend, 1908 (Guimarães 1971; Toma 2003), and its distribution ranges on Mexico, Guiana, Brazil (Amazonas, Santa Catarina, Paraná) and Paraguay (new record) (Toma 2003).

According to ASCLEPOL Database (Ollerton \& Liede 2010), a global compilation of anthophilous insects associated with Asclepiadoideae, there is a total of 24 tachinid entries (recognized as genera or species) recorded on 16 asclepiad species (Table I). The present note is the first record of a Neotropical tachinid on Asclepiadoideae, and only the fourth world record for Trichopodini (the other three with Nearctic species of Trichopoda Berthold, 1827 and Xanthomelanodes Townsend, 1893, Table I). Tachinid flies are characterized as having parasitoid larvae which grows inside arthropod hosts (mainly insects) and, because the regular flower visitation, the adults are considered nectarivores anthophilous, nonetheless the importance of flower to their bionomics is scarcely known (Larson et al. 2001).

Although this record supports E. sumichrasti as pollinaria carrier, there is no data in the literature whether it could be an effective pollinator. In ASCLEPOL Database, all the recordings of Tachinidae on Asclepiadoideae are characterized by observations of flies with pollinaria or pollinia attached to some part of the body. Under natural conditions, there is no evidence that tachinids are able to carry pollinia and transfer them to the flower's stigma. In fact, observation of effective pollination is very rare among the Diptera, with only two cases registered so far (for Sciaridae and Chloropidae species on Marsdenia cymulosa Benth. in Australia) (Ollerton \& Liede 2010).

This is the first anthophilous record to G. parviflorus, and also to genus Gonolobus. Previously, an undetermined species of Calliphoridae (Diptera) was recognized carrying pollinia of $G$. argentinensis T. Mey. in Argentina (Ollerton \& Liede 2010), but the current identity of this plant species is Matelea fiebrigii (Schltr.) Goyder (Goyder 2006). Another species of Matelea, M. reticulata (Engelm. ex A.Gray) Woodson from Mexico, was recorded as visited by an undetermined species of Tachinidae (Ollerton \& Liede 2010). Interestingly, Gonolobus and Matelea are both members of Gonolobinae, and cladistic analyses have indicated a close relationship (Rapini et al. 2003, 2007; Liede-Schumann et al. 2005; Krings et al. 2008) and, perhaps, they could even constitute a single broad genus (Krings et al. 2008). Despite any nomenclatural decision concerning Gonolobus and Matelea, this clade gathers three records in the Neotropics. More recently, Medeiros et al. (2008) reported the presence of pollinaria of two different species of Tassadia Decne. attached to the mouthparts of four species of Cerqueirellum Py-Daniel, 1983 (Diptera, Simuliidae) in Northern Brazil (Amazonia).
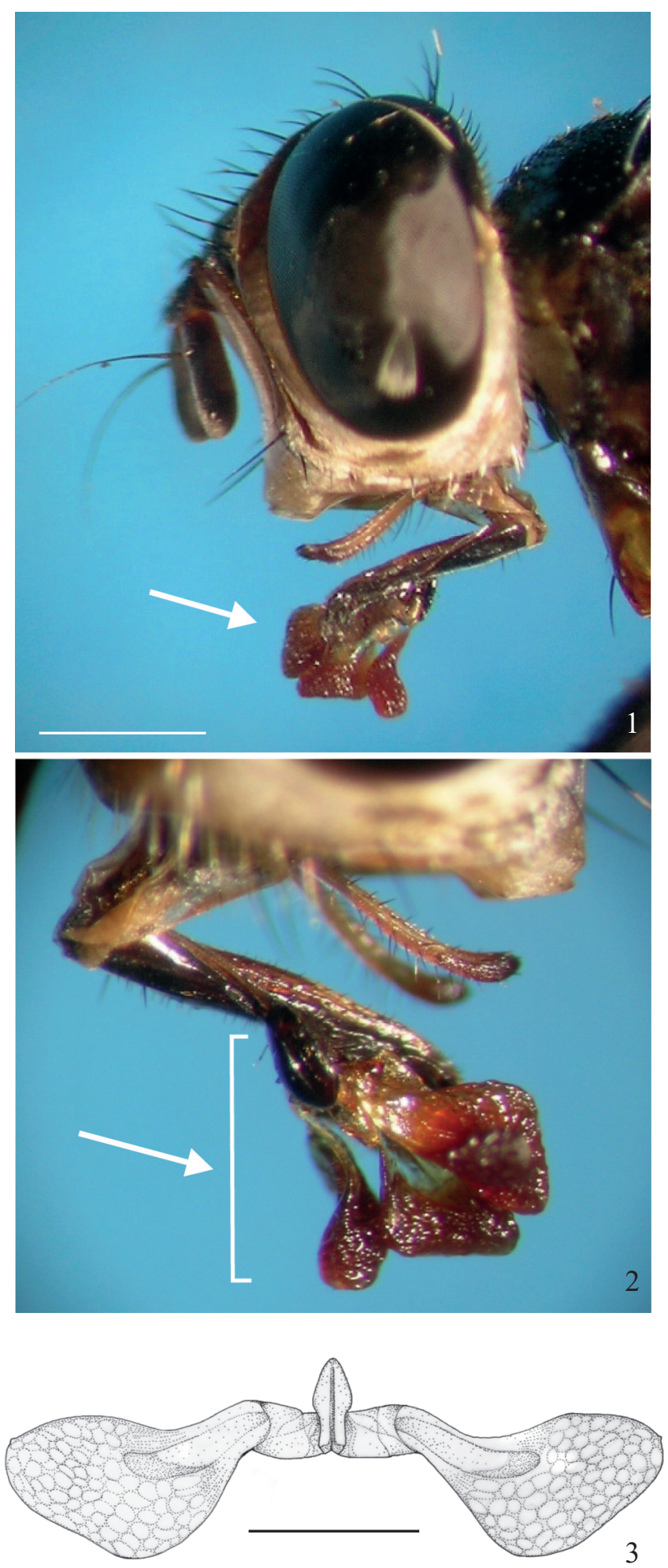

Figs. 1-3. 1, Head of Euacaulona sumichrasti Townsend in lateral view showing the pollinaria (indicated with arrow) attached to its proboscis; 2 , Detail of the proboscis and the pollinaria in the opposite view. Scale bar = $1 \mathrm{~mm} ; 3$, Pollinarium of Gonolobus parviflorus Decaisne found attached to the proboscis of Euacaulona sumichrasti. Scale bar $=410 \mu \mathrm{m}$. 
Table I. List of Asclepiadoideae species and their anthophilous Tachinidae species (from Ollerton \& Liede 2010). Plant species accompanied by their recording place; fly species accompanied by their systematic placement.

\begin{tabular}{|c|c|c|c|}
\hline Plant species (by subfamily) & Recording site & Tachinidae species & Tachinidae subfamily and tribe \\
\hline \multicolumn{4}{|l|}{ Asclepiadeae-Asclepiadinae } \\
\hline \multirow[t]{3}{*}{ Asclepias incarnata $\mathrm{L}$. } & USA & Gymnoclytia occidua (Walk.) & Phasiinae: Gymnosomatini \\
\hline & & Trichopoda lanipes (Fabr.) & Phasiinae: Trichopodini \\
\hline & & Panzeria sp. & Tachininae: Ernestiini \\
\hline \multirow[t]{2}{*}{ Asclepias purpurascens $\mathrm{L}$. } & USA & Spallanzania hesperidarum (Williston) & Exoristinae: Goniini \\
\hline & & Spallanzania sp. & Exoristinae: Goniini \\
\hline Asclepias speciosa Torr. & USA & Pararchytas decisus (Walk.) & \\
\hline \multirow[t]{5}{*}{ Asclepias syriaca $\mathrm{L}$. } & USA & Belvosia bifasciata (Fabr.) & Exoristinae: Goniini \\
\hline & & Belvosia unifasciata (R.-D.) & Exoristinae: Goniini \\
\hline & & Trichopoda plumipes (Fabr.) & Phasiinae: Trichopodini \\
\hline & & Linnaemyia sp. & Tachininae: Ernestiini \\
\hline & & Archytas analis (Fabr.) & Tachininae: Tachinini \\
\hline \multirow[t]{2}{*}{ Asclepias tuberosa $\mathrm{L}$. } & USA & Spallanzania hesperidarum & Exoristinae: Goniini \\
\hline & & Spallanzania sp. & Exoristinae: Goniini \\
\hline \multirow[t]{7}{*}{ Asclepias verticillata $\mathrm{L}$. } & USA & Spallanzania hesperidarum & Exoristinae: Goniini \\
\hline & & Spallanzania sp. & Exoristinae: Goniini \\
\hline & & Linnaemyia sp. & Tachininae: Ernestiini \\
\hline & & Archytas analis & Tachininae: Tachinini \\
\hline & & Archytas apicifer (Walk.) & Tachininae: Tachinini \\
\hline & & Cylindromyia euchenor (Walk.) & Phasiinae: Cylindromyiini \\
\hline & & Xanthomelanodes arcuatus (Say) & Phasiinae: Trichopodini \\
\hline \multicolumn{4}{|l|}{ Asclepiadeae-Metastelmatinae } \\
\hline Cynanchum formosum N.E.Br. & Peru & undet. Tachinidae & \\
\hline \multirow[t]{2}{*}{ Cynanchum leave (Michx.) Pers. } & USA & Phasia aeneoventris (Williston) & Phasiinae: Phasiini \\
\hline & & Panzeria sp. & Tachininae: Ernestiini \\
\hline Cynanchum viminale $\mathrm{L}$. & South Africa & undet. Tachinidae & \\
\hline \multicolumn{4}{|l|}{ Asclepiadeae-Astephaninae } \\
\hline Vincetoxicum nigrum (L.) Moen. & USA & undet. Tachinidae & \\
\hline \multicolumn{4}{|l|}{ Asclepiadeae-Gonolobinae } \\
\hline Matelea reticulata (Engelm. ex Gray) Woods. & Mexico & undet. Tachinidae & \\
\hline \multicolumn{4}{|l|}{ Marsdeniae } \\
\hline \multirow[t]{2}{*}{ Cosmostigma racemosa Wight } & India & Blepharipa sp. & Exoristinae: Goniini \\
\hline & & Lophosia imbuta (Wied.) & Phasiinae: Cylindromyiini \\
\hline Gymnema sylvestre (Retz.) Schultes & India & undet. Tachinidae & \\
\hline Marsdenia tenacissima Wight \& Arn. & India & undet. Tachinidae & \\
\hline \multicolumn{4}{|l|}{ Ceropegieae } \\
\hline Duvalia pubescens N.E.Br. & South Africa & undet. Tachinidae & \\
\hline Stapelia sp. & India & undet. Tachinidae & \\
\hline
\end{tabular}

Description of the pollinarium of G. parviflorus. Attached to the proboscis of $E$. sumichrasti there were one entire pollinarium and another pollinium bearing a single caudicle. Below we provide a morphological description of the pollinarium. Examination and morphometric data were made using an Olympus microscope, and drawings were made using the same microscope but coupled with a camara lucida.

Pollinarium (Fig. 3): Corpusculum with total lenght 0.222 $\mathrm{mm}$, lenght above caudicles $0.139 \mathrm{~mm}$, width at upper mid third $0.057 \mathrm{~mm}$, width at middle $0.090 \mathrm{~mm}$, width at lower mid third $0.065 \mathrm{~mm}$, sagitiform, clearly smaller than pollinia. Caudicles (or translator arms) with upper lenght 0.082-0.164 $\mathrm{mm}$, basal lenght $0.074-0.164 \mathrm{~mm}$, width at corpusculum $0.082-0.107 \mathrm{~mm}$, horizontal, articulated and with a reticulate membrane. Pollinia with lenght $0.609-0.683 \mathrm{~mm}$, width 0.312 $0.345 \mathrm{~mm}$, its shape from trapezoid to subromboid, sterile and excavate at about the center of proximal part (Morphological terminology following Newton 1984, and Kunze 1991, 1995). 
Geographical distribution of $\boldsymbol{G}$. parviflorus. Searching through online databases of non-Brazilian collections (CHG 2010; FMNH 2010; IBODA 2010; SMNH 2010; NYBG 2010), we found records of South American samples of G. parviflorus collected in Argentina, Bolivia, Ecuador, Peru, Paraguay and Brazil. In Brazil, it is represented by less than 20 specimens from the states of Mato Grosso do Sul, Minas Gerais, Rio de Janeiro, São Paulo, Paraná and Santa Catarina. In Paraguay, there are records by the collectors Hassler and Fiebrig (CHG 2010; IBODA 2010) which account a total of eight specimens (this material are referred to under the names Gonolobus selloanus (E.Fourn.) Bacigalupo or Exolobus selloanus E.Fourn., which are currently junior synonyms of $G$. parviflorus). There is no record of $G$. parviflorus for the locality from which the tachinid fly was captured (Departamento Canindeyú, Estancia Rio Corrientes). The Departamento Canindeyú is characterized by dry and riparian forests of the Atlantic Forest biome, and these are mostly preserved within conservation units close to the boundary with Brazil (Spichiger et al. 1992; Monge 2009). The preferred habitats of $G$. parviflorus are the sunspots and the forest edges (Fontella-Pereira et al. 1985).

The geographical distribution of G. parviflorus ranges from Ecuador, Peru, Bolivia, Brazil (Mato Grosso do Sul, Minas Gerais, Rio de Janeiro, São Paulo, Paraná and Santa Catarina), Argentina and Paraguay (Fontella-Pereira et al. 1985; CHG 2010; FMNH 2010; IBODA 2010; SMNH 2010; NYBG 2010).

\section{ACKNOWLEDGEMENTS}

Thanks to Claudio J. B. de Carvalho (Departamento de Zoologia, Universidade Federal do Paraná) for the loan of the Diptera specimen. Financial support to SSN from FAPESP (proc. 04/13663-9 and 07/50836-7) and CNPq (proc. 303897/ 2008-2) and to EAS from CNPq (proc. 480660/2004-2). Thanks to Dalton R. dos Santos for the final drawing of the pollinarium.

\section{REFERENCES}

CHG. 2010. Base de donnés (Catalogue des Herbiers de Genève). Available from http://www.ville-ge.ch/musinfo/bd/cjb/chg/index.php?an. (accessed 25 July 2010).

Faegri, K. \& L. van der Pijl. 1980. The principles of pollination ecology. 3ed. Oxford, Pergamon Press, 244 p.

FMNH. 2010. Botany Collections Database. Available from http://emuweb. fieldmuseum.org/botany/taxonomic.php. (accessed 27 July 2010).

Fontella-Pereira, J.; G. Hatschbach \& R. W. Hartmann. 1985. Contribuição ao estudo das Asclepiadaceae do Paraná, III. Notas preliminares. Boletim do Museu Botânico Municipal de Curitiba 64: 1-47.

Goyder, D. J. 2006. Rojasia reinstated and six new names and combinations in Matelea (Apocynaceae: Asclepiadoideae). Kew Bulletin 61:31-33.

Guimarães, J. H. 1971. 104. Family Tachinidae. In: A catalogue of the Diptera of the Americas South of the United States. São Paulo, Museu de Zoologia, Universidade de São Paulo, 333 p.
IBODA. 2010. Colecciones de ejemplares del Herbário - Instituto de Botânica Darwinion. Available from http://www2.darwin.edu.ar/ Herbario/Bases/BuscarIris.asp. (accessed 25 July 2010).

Kevan, P.G. \& H. G. Baker. 1983. Insects as flower visitors and pollinators. Annual Review of Entomology 28: 407-453.

Knuth, P. 1909. Handbook of flower pollination. Goodenovieae to Cycadeae. v.3. Oxford, Clarendon Press, 644 p.

Krings, A.; D. T. Thomas \& Q. J. Xiang. 2008. On the generic circunscription of Gonolobus (Apocynaceae, Asclepiadoideae): evidence from molecules and morphology. Systematic Botany 33: 403-415.

Kunze, H. 1991. Structure and function in asclepiad pollination. Plant Systematics and Evolution 176: 227-253.

Kunze, H. 1995. Floral morphology of some Gonolobeae (Asclepiadaceae). Botanische Jahrbücher für Systematik, Pflanzengeschichte und Pflanzengeographie 117: 211-238.

Larson, B. M. H.; P. G. Kevan \& D. W. Inouye. 2001. Flies and flowers: taxonomic diversity of anthophiles and pollinators. Canadian Entomologist 133: 439-465.

Liede-Schumann, S.; A. Rapini; D. J. Goyder \& M. W. Chase. 2005. Phylogenetics of the New World subtribes of Asclepiadeae (ApocynaceaeAsclepiadoideae): Metastelmatinae, Oxypetalinae, and Gonolobinae. Systematic Botany 30: 183-194.

Medeiros, J. F.; A. Rapini; U. C. Barbosa; V. Py-Daniel \& P. L. S. Braga. 2008. Primeiro registro de Simuliidae (Diptera) com polinários de Asclepiadoideae (Apocynaceae). Neotropical Entomology 37: 338-341.

Monge, V. R. V. 2009. Comparação de associações vegetais sobre diferentes tipos de solos na área de influência da Represa Itaipu, para reconhecimento de espécies apropriadas para restauração ecológica. Tese de Doutorado, ESALQ-USP. Available from http://www.teses. usp.br/teses/disponiveis/11/11150/tde-10092009-103258/pt-br.php. (acessed 26 July 2010).

NYBG. 2010. The C. V. Starr Virtual Herbarium (New York Botanical Garden). Available from http://sciweb.nybg.org/science2/vii2.asp. (accessed 26 July 2010).

Newton, L. E. 1984. Terminology for structures associated with pollinia of the Asclepiadaceae. Taxon 33: 619-621.

Ollerton, J. \& S. Liede. 1997. Pollination systems in the Asclepiadaceae: a survey and preliminary analysis. Biological Journal of the Linnean Society 62: 593-610.

Ollerton, J. \& S. Liede. 2010. The ASCLEPOL Database. Available from http://www.old.uni-bayreuth.de/departments/planta2/research/pollina/ as_pol_t.html. (accessed 13 March 2010).

Perry, L. M. 1938. Gonolobus within the Gray's Manual Range. Rhodora 40 (476): 281-287.

Rapini, A.; M. W. Chase; D. J. Goyder \& J. Griffiths. 2003. Asclepiadeae classification: evaluating the phylogenetic relationships of New World Asclepiadoideae (Apocynaceae). Taxon 52: 33-50.

Rapini, A.; C. van den Berg \& S. Liede-Schumann. 2007. Diversification of Asclepiadoideae (Apocynaceae) in the New World. Annals of the Missouri Botanical Garden 94: 407-422.

Schill, R. \& U. Jäkel. 1978. Beitrag zur Kenntnis der AsklepiadaceenPollinarien. Tropische und subtropische Pflanzenwelt 22: 53-170.

SMNH. 2010. Krypto-S: Botanical database at Swedish Museum of Natural History. Available from http://www.nrm.se/en/menu/ researchandcollections/collections/databases/kryptos.8598_en.html. (accessed 28 July 2010).

Spichiger, R.; Bertoni, S.B.; Chautems, A.; Loizeau, P. A. 1992. The forests of Paraguayan Alto Paraná. Candollea 47: 219-250.

Toma, R. 2003. Estudo das species do "complexo Acaulona" sensu Sabrosky (Diptera, Tachinidae). Revista Brasileira de Entomologia 47: 267-282.

Vieira, M. F. \& G. J. Sheperd 1999. Pollinators of Oxypetalum (Asclepiadaceae) in Southeastern Brazil. Revista Brasileira de Biologia 59: 693-704. 